\title{
Increasing doses of cattle manure for organic chili pepper production
}

\author{
João Victor Silva Ribeiro', Leandra Regina Semensato ${ }^{1}$, Eduardo Pradi Vendruscolo² \\ ${ }^{1}$ UNIGOIÁS, Centro Universitário de Goiás, Goiânia, Goiás, Brasil. E-mail: joaovitorevangelista@ hotmail.com, \\ ledocepe@gmail.com \\ ${ }^{2}$ Universidade Estadual de Mato Grosso do Sul, Unidade Universitária de Cassilândia, Cassilândia, Mato Grosso do Sul, Brasil. \\ E-mail: agrovendruscolo@gmail.com
}

Received: 20/06/2020; Accepted: 22/07/2020.

\begin{abstract}
There is a contemporary trend of change in the agricultural sector, aiming at the use of ecologically friendly inputs. This trend can be seen by the constant increase in the demand for organic products. However, as with other technologies, there is a need for studies to evaluate the effectiveness of its use. The present study aimed to evaluate the effects of the application of increasing doses of cattle manure on the development and productivity of chili peppers. The treatments consisted of increasing doses of cattle manure $\left(0 ; 5 ; 10 ; 15 ; 20 \mathrm{Mg} \mathrm{ha}^{-1}\right)$. The variables plant height, stem diameter, number of plant leaves and length, diameter, and fruit yield were evaluated. It was found that, with the maximum amount of cattle manure, there was an increase of $35.96 \%, 41.12 \%, 47.84 \%$, and $161.64 \%$ concerning the control treatment, without the cattle manure application. Thus, it was concluded that the use of increasing doses of cattle manure, up to $20 \mathrm{Mg} \mathrm{ha}^{-1}$, is beneficial to the development and production of chili pepper.
\end{abstract}

Keywords: Capsicum frutescens, organic fertilizer, sustainable production, agro-industrial waste, spice crop.

\section{Doses crescentes de esterco bovino para a produção de pimentas orgânicas}

\section{RESUMO}

Há uma tendência contemporânea de mudança no setor agrícola, visando a utilização de insumos ecologicamente amigáveis. Essa tendência pode ser observada pelo aumento constante da demanda por produtos orgânicos; porém, como para as demais tecnologias, há a necessidade de estudos que avaliem a eficácia da sua utilização. O presente estudo teve como objetivo avaliar os efeitos da aplicação de doses crescentes de esterco bovino no desenvolvimento e produtividade de pimentas. Os tratamentos consistiram em doses crescentes de esterco bovino $(0 ; 5 ; 10 ; 15 ; 20$ $\left.\mathrm{Mg} \mathrm{ha}^{-1}\right)$. Foram avaliadas as variáveis altura da planta, diâmetro do caule, número de folhas e comprimento da planta, diâmetro e produção de frutos. Verificou-se que, na quantidade máxima de esterco bovino, houve um aumento de $35,96 \%, 41,12 \%, 47,84 \%$ e $161,64 \%$ em relação ao tratamento controle, sem a aplicação de esterco bovino. Assim, concluiu-se que o uso de doses crescentes de esterco bovino, até $20 \mathrm{Mg} \mathrm{ha}^{-1}$, é benéfico para o desenvolvimento e produção de pimenta.

Palavras-chave: Capsicum frutescens, fertilizante orgânico, produção sustentável, rejeito agroindustrial, cultura condimentar. 
Worldwide, there is a demand for more sustainable production systems with less use of pesticides and synthetic fertilizers (Vendruscolo et al., 2018). Many questions are raised when discussing the long-term socioeconomic and environmental viability of conventional agriculture (Muller et al., 2017), including redirecting scientific efforts in this direction. One of the agricultural sectors most strongly influenced by organic food production strategies is horticulture. Much of this influence is due to the characteristic of this type of production being carried out mainly on small properties, which use family labor and have production variability, usually with the integration of livestock, as observed in emerging countries like Brazil (Silva Júnior et al., 2018).

The use of organic waste is a good strategy to minimize production costs, as it promotes a reduction in cultivation time and consumption of synthetic inputs, such as pesticides and fertilizers since these inputs are responsible for a considerable part of the costs in the plant product production (Vendruscolo et al., 2019). The supply of animal production residues can also improve soil characteristics, increasing the levels of organic carbon (Martínez et al., 2017), microbiological activity, and diversity, besides the availability of nutrients (Das et al., 2017; Luqui et al., 2019).

Specifically, for peppers production, there are many positive effects on the development of vegetative organs (Jamir et al., 2017; Silva et al., 2018) and productivity (Silva et al., 2019) of plants when used organic fertilizers. Also, in the composition of pepper fruits, it was found that the use of organic fertilizers from animal production increases the levels of antioxidant compounds, such as phenolic acid, flavonoids, and carotenoids (Hallmann et al., 2019). The high variability in response is due to the vast amount of peppers used in world cuisine, requiring specific studies to increase efficiency during production.

Given the above, the present study aimed to evaluate the effects of the application of increasing doses of cattle manure on the development and productivity of chili peppers (Capsicum frutescens L.).

The experiment was conducted in Aragoiânia, the state of Goiás, at $16^{\circ} 54^{\prime} 47.1^{\prime \prime} \mathrm{S}, 49^{\circ} 27^{\prime} 52.8^{\prime \prime} \mathrm{W}$, and elevation of $779 \mathrm{~m}$. The average annual temperature is $22.6^{\circ} \mathrm{C}$, and the average annual rainfall is $1,454 \mathrm{~mm}$. The soil of the experimental area was classified as Latossolo Vermelho amarelo (Oxisol) (Santos et al., 2018) and presents the following chemical characteristics in the 0.0-0.2 m layer: $27.02 \mathrm{~g} \mathrm{~kg}^{-1}$ of organic matter (MO); $\mathrm{pH}\left(\mathrm{CaCl}_{2}\right) 4.9 ; 2.31$ $\mathrm{mg} \mathrm{dm}{ }^{-3} \mathrm{P}$ (Mehlich); $62.0 \mathrm{mg} \mathrm{dm}^{-3} \mathrm{~K} ; 4.0 \mathrm{cmolc} \mathrm{dm}^{-3} \mathrm{Ca}$; $1.0 \mathrm{cmolc} \mathrm{dm}{ }^{-3} \mathrm{Mg} ; 8.30 \mathrm{mg} \mathrm{dm}^{-3} \mathrm{Mn} ; 4.20 \mathrm{mg} \mathrm{dm}^{-3} \mathrm{Cu}$; $54 \mathrm{mg} \mathrm{dm}^{-3} \mathrm{Fe} ; 5.20 \mathrm{mg} \mathrm{dm}^{-3} \mathrm{Zn} ; 0.32 \mathrm{mg} \mathrm{dm}^{-3} \mathrm{~B} ; 0.1 \mathrm{mg}$ $\mathrm{dm}^{-3} \mathrm{H}+\mathrm{Al} ; 6.76 \mathrm{cmolc} \mathrm{dm}^{-3} \mathrm{CTC} ; 76.32$ of V\%.
The randomized block design with five treatments and four repetitions was used. The five treatments were: $\mathrm{T} 1$ - control treatment, without manure; $\mathrm{T} 2$ - $5 \mathrm{Mg} \mathrm{ha}^{-1}$ of manure; $\mathrm{T} 3$ - $10 \mathrm{Mg} \mathrm{ha}^{-1}$ of manure; $\mathrm{T} 4-15 \mathrm{Mg} \mathrm{ha}^{-1}$ of manure; and T5 - $20 \mathrm{Mg} \mathrm{ha}^{-1}$ of manure. Cattle manure applications were carried out in two moments, half of the dose in the planting pit, at the time of transplant, and after 45 days as topdressing fertilization. Rice husk (300 g) was deposited around the seedling to avoid excessive loss of soil moisture.

The soil in the experimental area was plowed for homogenization. Then, seedlings, from a commercial nursery in the region, were transplanted. The transplant took place in March 2019, when the seedlings presented approximately $15 \mathrm{~cm}$ in height. The spacing used was 1 meter between plants by 1.5 meters between lines. The total area was $270 \mathrm{~m}^{2}$, divided into twenty plots of 13.5 $\mathrm{m}^{2}$ each and with nine plants per plot.

Monitoring was carried out daily to check for the occurrence of pests and diseases; however, no action was necessary for control purposes. For weed elimination, two manual weeding operations were carried out, preventing them from competing with pepper plants for environmental resources.

Data were collected from the following variables: Height of plant: measured with a tape measure, from the base of the plant to the maximum height of the canopy. Height was measured when $100 \%$ of the plants had at least one ripe fruit ( 3 months after transplanting); Stem diameter: measured with a digital caliper when $100 \%$ of the plants had at least one ripe fruit; Number of leaves: counted when $100 \%$ of the plants presented at least one ripe fruit (3 months after transplanting); Fruit length and diameter: measured with a digital caliper after harvesting the fruits; Productivity: calculated as the multiplication of the fruit mass obtained per plant by the number of plants present in $1000 \mathrm{~m}^{2}$.

The average data of the variables were submitted to regression analysis at $5 \%$ probability. The statistical program used was Sisvar 5.6 (Ferreira, 2014).

There was no significant difference in the variables of length, diameter, and fruit mass between the doses of cattle manure used in the study. However, for the other variables, there was a positive effect as the doses increased.

There was a linear, and positive effect for plant height, stem diameter, the number of leaves, and pepper fruit yield as the levels of cattle manure increased to 20 $\mathrm{Mg} \mathrm{ha}{ }^{-1}$ (Figure 1). The maximum dose provided an increase of $35.96 \%, 41.12 \%, 47.84 \%$, and $161.64 \%$ compared to the control treatment, without the application of cattle manure. 

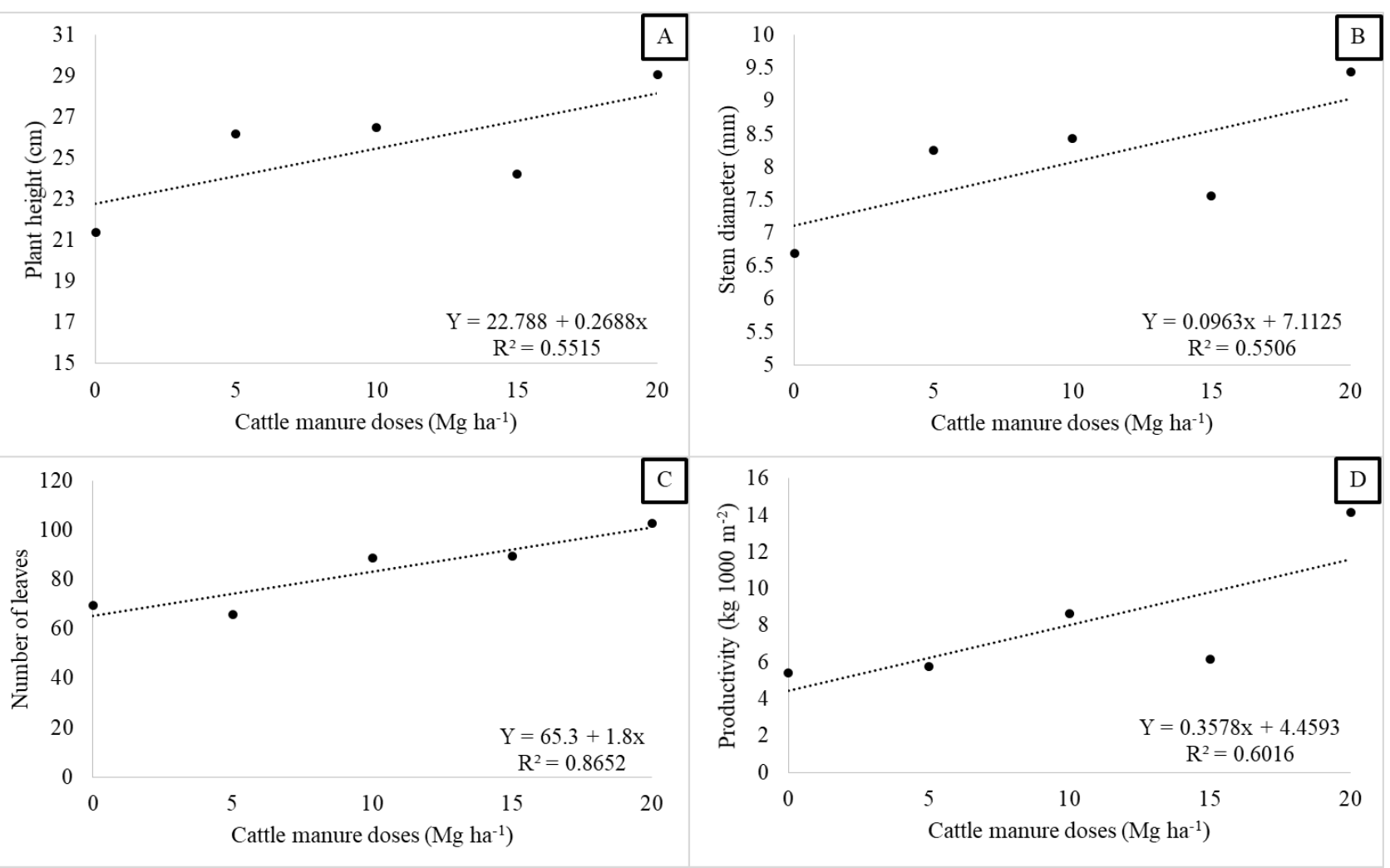

Figure 1. Plant height, stem diameter, number of leaves, and chili pepper yield grown with different dosages of cattle manure.

There are several factors involved in the increase of vegetative development and the productivity of pepper through the application of cattle manure. One of the main ones is the supply of nutrients to plants, since the passage of organic materials through the digestive system of animals and subsequent action by decomposing microorganisms results in a reduction in the size of particles and mineralization of nutrients, making them readily accessible to vegetables (Eckhardt et al., 2018). In this sense, it appears that the use of manure increases the edaphic levels of macro and micronutrients in their forms most assimilable by plants (Schlegel et al., 2017).

The application of cattle manure also results in increased levels of organic carbon in the soil (BlancoCanqui et al., 2017). This increase reflects a series of positive changes, such as an increase in macro and microbiological activity (Guo et al., 2016; Das et al., 2017), improvements in physical characteristics, such as aggregate stability, porosity, among others (Yagüe et al., 2016), which in turn increase soil aeration and conditions for infiltration and water retention (Ozlu et al., 2019).

Based on the results obtained, it can be inferred that cattle manure can be used for the production of chili peppers. However, further studies are necessary, since the observed increases tend to be greater in higher doses than those studied. Also, one must observe the source and form of application, considering that manure from different conditions of animal husbandry and subsequent treatment may result in environmental contamination (Ramos et al., 2020).
Advances in organic agriculture have contributed to the success of this type of production system. Besides the benefits of obtaining food, there is a sustainability bias, while waste from agribusiness can be used. These residues, when used in agriculture, have their potential for contamination reduced and become part of the food chain, also resulting in a decrease in the dependence on the use of synthetic fertilizers.

The use of increasing doses, up to $20 \mathrm{Mg} \mathrm{ha}^{-1}$, of cattle manure positively affects the development and productivity of chili pepper plants.

\section{Bibliographic References}

Blanco-Canqui, H., Francis, C.A., Galusha, T.D., 2017. Does organic farming accumulate carbon in deeper soil profiles in the long term? Geoderma, 288, 213-221.

Das, S., Jeong, S.T., Das, S., Kim, P.J., 2017. Composted cattle manure increases microbial activity and soil fertility more than composted swine manure in a submerged rice paddy. Frontiers in Microbiology, 8, 1702.

Eckhardt, D.P., Redin, M., Santana, N.A., Conti, L.D., Dominguez, J., Jacques, R.J.S., Antoniolli, Z.I., 2018. Cattle Manure Bioconversion Effect on the Availability of Nitrogen, Phosphorus, and Potassium in Soil. Revista Brasileira de Ciência do Solo, 42, e0170327, 1-10.

Ferreira, D.F., 2014. Sisvar: a Guide for its Bootstrap procedures in multiple comparisons. Ciência e Agrotecnologia, 38(2), 109-112. 
Guo, L., Wu, G., Li, Y., Li, C., Liu, W., Meng, J., Liu, H., Yu, X., Jiang, G., 2016. Effects of cattle manure compost combined with chemical fertilizer on topsoil organic matter, bulk density and earthworm activity in a wheat-maize rotation system in Eastern China. Soil and Tillage Research, 156, 140-147.

Hallmann, E., Marszałek, K., Lipowski, J., Jasińska, U., Kazimierczak, R., Średnicka-Tober, D., Rembiałkowska, E., 2019. Polyphenols and carotenoids in pickled bell pepper from organic and conventional production. Food Chemistry, 278, 254-260.

Jamir, T., Rajwade, V.B., Prasad, V.M., Lyngdoh, C., 2017. Effect of organic manures and chemical fertilizers on growth and yield of sweet pepper (Capsicum annuиm L.) hybrid Indam Bharath in shade net condition. International Journal of Current Microbiology and Applied Sciences, 6(8), 1010-1019.

Luqui, L.L., Salles, J.S., Costa, E., Alves, V.C.D., Souza, L.G.P., Vieira, M.T., Salles, J.S., Sousa, V.C.M., 2019. Seedlings production and fruit yield of cucumber on different organic substrates. Journal of Neotropical Agriculture, 6(4), 17.

Martínez, E., Domingo, F., Roselló, A., Serra, J., Boixadera, J., Lloveras, J., 2017. The effects of dairy cattle manure and mineral $\mathrm{N}$ fertilizer on irrigated maize and soil $\mathrm{N}$ and organic C. European Journal of Agronomy, 83, 78-85.

Muller, A., Schader, C., Scialabba, N.E.H., Brüggemann, J., Isensee, A., Erb, K.H., Smith, P., Klocke, P., Leiber, F., Stolze, M., Niggli, U., 2017. Strategies for feeding the world more sustainably with organic agriculture. Nature Communications, $8(1), 1-13$.

Ozlu, E., Sandhu, S.S., Kumar, S., Arriaga, F.J., 2019. Soil health indicators impacted by long-term cattle manure and inorganic fertilizer application in a corn-soybean rotation of South Dakota. Scientific reports, 9(1), 1-11.

Ramos, M.L., Moscuzza, C.H., Cirelli, A.F., 2020. Total content and availability of micronutrients in soils and livestock manure. Revista Internacional de Contaminación Ambiental, 36(1), 115-126.
Santos, H.G., Jacomine, P.K.T., Anjos, L.H.C., Oliveira, V.A., Lumbreras, J.F., Coelho, M.R., Almeida, J.A., Araujo Filho, J.C., Oliveira, J.B., Cunha, T.J.F., 2018. Sistema brasileiro de classificação de solos. Embrapa, Brasília.

Schlegel, A.J., Assefa, Y., Bond, H.D., Haag, L.A., Stone, L.R., 2017. Changes in soil nutrients after 10 years of cattle manure and swine effluent application. Soil and Tillage Research, 172, 48-58.

Silva Júnior, V.E., Vendruscolo, E.P., Semensato, L.R., Campos, L.F.C., Seleguini, A., 2018. Esterco bovino como substrato alternativo na produção de mudas de melão. Revista Agropecuária Técnica, 39(2), 112-119.

Silva, S.P., Viégas, I.J.M., Okumura, R.S., Silva, D.A.S., Galvão, J.R., Silva Júnior, M.L., Araújo, F.R.R., Mera, W.Y.W.L., Silva, A.O., 2018. Growth and Micronutrients Contents of Smell Pepper (Capsicum chinense Jac.) Submitted to Organic Fertilizer. Journal of Agricultural Science, 10(11), 425-435.

Silva, V.F., Bezerra, C.V., Nascimento, E., Ferreira, T.N., Lima, V.L., Andrade, L.O., 2019. Production of chili pepper under organic fertilization and irrigation with treated wastewater. Revista Brasileira de Engenharia Agrícola e Ambiental, 23(2), 84-89.

Vendruscolo, E.P., Rodrigues, A.H.A., Correia, S.R., Oliveira, P.R., Campos, L.F.C., Seleguini, A., 2019. Economic analysis of crisp lettuce production in different planting spacing and soil cover. Advances in Horticultural Science, 33(4), 449-455.

Vendruscolo, E.P., Siqueira, A.P.S., Furtado, J.P.M., Campos, L.F.C., Seleguini, A., 2018. Development and quality of sweet maize inoculated with diazotrophic bacteria and treated thiamine. Revista de Agricultura Neotropical, 5(4), 45-51.

Yagüe, M.R., Domingo-Olivé, F., Bosch-Serra, À.D., Poch, R.M., Boixadera, J., 2016. Dairy cattle manure effects on soil quality: porosity, earthworms, aggregates and soil organic carbon fractions. Land Degradation \& Development, 27(7), 1753-1762. 